\title{
STUDENTS' CULTURAL AWARENESS LEVEL AND THEIR TECHNIQUES FOR INCORPORATING TARGET CULTURAL CONTENT INTO ENGLISH LANGUAGE TEACHING IN ENGLISH TEACHER EDUCATION DEPARTMENT OF UIN SUNAN AMPEL SURABAYA
}

\author{
Qori'ah Maghfirotillah \\ Email: qoriah.maghfiroh@gmail.com \\ International Office \\ UIN Sunan Ampel Surabaya
}

\begin{abstract}
Having cultural awareness deals much more with ones' ability to face global interaction and to communicate appropriately, and thus, is crutial for students taking micro-teaching class of ETED UIN Surabaya as English teacher candidates. To gain meaningful English teaching, ETED students need to highlight that language learning without involving any cultural contents means nothing. This paper is a literature review of the bigger study which aims to examine the level of Students' cultural awareness in micro teaching class of English Teacher Education Department and the strategies that are used by students of micro teaching class to incorporate cultural aspect into their English language teaching.
\end{abstract}

Keywords: level of cultural awareness, micro-teaching class, Intercultural Competence

\section{INTRODUCTION}

After the implementation of Asian Free Trade Area (AFTA) in December 31, 2015, having cultural awareness becomes something critical for every people. The logic is that the implementation of AFTA will bring people to easily come, live, and possibly work in other countries. There will be a lot of people from other countries having different cultures coming, trading, and interacting in Indonesia. Facing this fact, cultural awareness is extremely needed to build a good communication in which people can tolerate diversity and commend others appropriately. 
The irony is that the use of foreign languages is something less in Indonesia. It is confirmed by the data of World Bank stating that the discrepancy of foreign language ability of using among man power in Indonesia is about $44 \%$ (Kurniansah, 2015). This might be caused by the fact that the language is learned without giving meaning. Then, cultural awareness here is also needed in order that ones can use English appropriately. AFTA will open the chance for all people in South of Asia speaking different languages and not using English as the first language to interact each other. This case becomes possibility to make English as lingua franca as its function as an international language. Indeed, it is important to learn English contextually.

In learning a foreign language, teachers or lecturers should transfer not only the linguistic items but also the cultural evidence that is adhered in the target language itself (Deardoff, 2004: 14). It is positively a must in order that the students can comprehensively master the target language since the items in every language cannot be separated from the cultural context. This is synchronic with the purpose of language learning in 2013 curriculum.

The 2013 curriculum highlights that classroom teachinglearning process should give any impact to students' daily life and the way they interact with the society. Integrating culture and language together in a teaching becomes a solution to make English learning more practical. This demand stated in the regulation of Indonesian Minister of Education and Culture No. 70 Year 2013 about the basic outline and structure of Sekolah Menengah Kejuruan or Madrasah Aliyah Kejuruan. He said that school should be media for students to learn everything they can use in their society. Thus, what is learned in school needs to be applicable and meaningful (Kemendikbud, 2013: 6).

Meanwhile, the second main competence of 2013 curriculum of English lesson also states that the purpose of teaching English is to make students aware on the way how to behave in global interaction. Hence, cultural awareness is needed in this case, since as expected by the regulation of Indonesian Minister of Education and Culture No. 70 Year 2013 about the basic outline and structure of Sekolah Menengah Kejuruan or Madrasah Aliyah Kejuruan, students learning foreign 
language will realize their role as a representation of nation in the international relations.

English is one of the languages that are commonly learned by people from the entire world because of its role as an international language. English learned as a communication medium between people to people in international relationship. Considering this reason, it is clear that in studying English, students are not only expected to understand the structure of English itself, but also to have intercultural competence or to understand the concept of language use in real life context (Schulz, 2007: 9).

The ability to gain intercultural competence is called as cultural awareness. Cultural awareness is very important to bridge students in understanding the target culture that may be very different from their own culture. By having cultural awareness, students will be able to know others' culture. This knowledge ideally can be used to strengthen their own culture and identity, because the interaction between cultures ideally should create a reinvention of local tradition and identity (Schulz, 2007: 14). In addition, students also will be able to use their understanding about a language appropriately looking from the behavior, value, faith, and cultural background of the target language studied.

In this matter of fact, it is important to know to what techniques used by the students of English Education Department because they will be teachers in the future who are demanded to not only transfer linguistic competence to the students but also to transfer cultural content as a bridge for students to understand about cultural diversity and the way to respect and face it. In assumption, it will be difficult to raise students' awareness about the culture if the teachers themselves do not know exactly what the culture of the target language is.

As an initiation, it is believed that the level of students' cultural awareness deals and even relates strightly with students' competence to be a teacher. As the consequence, the result of this research can be made as a reflection for the department to know whether the students of English Teacher Education Department are ready or not to face the demand to incorporate any cultural knowledge they can transfer into 
their English teaching. Another benefit is that this research finding will give information to the world dealing with the relationship between teacher's levels of cultural awareness and the techniques they use to incorporate cultural knowledge in foreign language teaching, especially English.

The students of Micro teaching class of English Education Department (PPL 1) is chosen as the subjects since they have taken Cross Culture Understanding Class to learn about the way how to appreciate others' culture and how to face the differences. Then, they are also regarded having better understanding of English since they are equipped by knowledge and skills to be an English techer for five semesters in the university. They have taken all courses enriching their pedagogical needs, such as TEFL, Curriculum Development, IMALT, and vice versa. Moreover, in micro-teaching class, students are directed and trained to teach correctly.

As teachers' candidate, the students should have a good cultural awareness. Later, after graduating from State Islamic University of Sunan Ampel Surabaya, they should be able to teach their student, transfer the information not only from the linguistic rule but also from the culture. The ability to incorporate culture in language teaching will benefit for both teacher and students to strengthen and improve their English proficiency. As the result, it is important to assess their readiness to face that demand.

In order to use English that is culturally appropriate, English teacher candidates need to know the way how to incorporate cultural context in their teaching, and they would practice doing it in PPL 1 class. As well, it gives lecturers guidelines about what to do in their teaching. The lecturers will benefit a view dealing with how to teach their students in order that they can be good teachers in the future who can incorporate cultural context in their teaching.

Based on the background, the study attempts in answering these questions: (1) what the level of Students' cultural awareness in micro teaching class of English Teacher Education Department, and (2) what are the techniques used by students of micro teaching class to incorporate cultural aspect into their English language teaching. 


\section{CULTURE AND CULTURAL AWARENESS}

Empirically, culture is one of the components that cannot be separated from one's life. It is already glued into any interaction among people around the world. The world culture is easy to find, to hear, to say, but hard to define. When it is defined, there will be many interpretations through any field of science; anthropology, sociology, linguistic, and many others. Each field will define culture differently. It is synchrony with what Barker says that culture does not have any exact and definitive meaning (2008).

However, as cited by Hofsted, Kluckhohn quotes a definition of culture as the way how people think, feel, and react in particular way which then internalized and transmitted through symbols, work, opus, and so on. The essence of culture is developed the traditional ideas and values. Furthermore, Hofsted cites the definition of culture according to Kroeber's and Parsons's perspective. They define culture as the concept of values, meaning, and ideas which is transmitted and developed generation to generation as something to shape human behavior and artifacts (Hofsted, 1981: 23). From this definition, it can be inferred that culture is anything in one's life that is resulted from the interaction among them. It can be the way how the people socialize, how they pour their ideas into such kind of art, how their belief is, how they run their life, and others.

Culture itself is divided into two categories. The first is material culture or what is called by people as surface culture, and the second is immaterial culture or deep culture (Notez, 2013). It is synchrony with what Moran states in his book that the categorization of culture is manifested in an iceberg model which a half of its part is under the water (Moran, 2001: 55). The top part of the iceberg is surface culture in analogy, and the hidden part is the deep culture.

Surface or material culture is defined as any kind of culture that is obvious to observe. It is primarily in awareness. The examples of this kind of culture are: fine arts, food, clothing, and others. Meanwhile, immaterial or deep culture is defined as any kinds of culture that is less obvious and unclear. The production of this culture is out of awareness, for instance: attitudes, beliefs, religion, and so on. 
One of intercultural competence is cultural awareness. It is defined as a general understanding of learner to world cultures, emphasizing on how they can recognize the differences and similarities among those cultures. In terms of English as foreign language (EFL) learning, cultural awareness will enable the learners to find the difference and similarity between the culture of native English countries; UK and USA, and then compare it with their own culture. In this case, learners also will have any competence to judge a cultural situation resulting from the condition of each country.

The awareness of culture is extremely important because the awareness itself will be a basic knowledge that will deal with the way how learners use their target language in context (Kuhi, 2013: 516). For example: it will be less appropriate if learners use a term, a word, or an expression of target language without knowing the use; how it is used in the native English country. As the reason, it is important for learners to acquire any target cultural knowledge through language learning to train their discourse sensitivity.

According to Bianco, Liddicoat, and Crozet, there are several uses of cultural awareness in language teaching (1999: 66). Firstly, it is to build the knowledge of other societies and cultures. It is important to help learners having a good behavior when they face cultural diversity. Secondly, it is to build empathy. Empathy here functions as the bridge that connects the feeling of learners into the condition of target language culture they learn. Thirdly, it is to build approval. Approval is important to help the learners avoiding ethnocentrism, or racism; how they can see any culture from several dimensions (Byram and Feng, 2004: 149). Fourthly, it is to enable learners in passing task performance. It deals with the preparation of them to be able to use the target language as a foreigner in several needed context.

Considering the importance of the transmission of cultural knowledge through language learning, it is also important to assess how success it is acquired by students. Assessing is a part of teaching and it is a must to conduct (Brown, 2003: 5). By assessing, teachers will know in what level their students are, what to be improved, and so on. So does in language teaching; both communicative and intercultural competence should be well assessed. 
According to the World Languages (2011), there are four things that can be tested dealing with cultural awareness, they are: Factual knowledge (the way how they interact with cross cultural knowledge), Intercultural skill (how they interpret any cultural information that seems abstract and contradictive for them), understanding values and perspectives (how they can catch the value, ideology and morality) and the last is personal engagement (how well they can present their cultural knowledge, and how well those information effects the belief, attitudes, and others).

But here this current study is only focused on two aspects; factual knowledge and intercultural skills. The reason was because the two aspects (understanding values and perspectives) are already covered by the second aspects, intercultural skill. For the reason, intercultural skill deals with the way how people set their view and attitudes toward other culture outside them, including how people interpret the values and how they see the differences through their own perspective.

World Language SAC employs 4 levels of cultural awareness in which it describes one's achievement facing target cultural content (2011). In other words, the following levels of cultural awareness describe what people actually able to do facing target cultural content:

a. Level 1 or description and identification, here ones are only able to do description and identification. The ability of them in term of factual knowledge is only mentioning, discovering, or identifying target cultural practices without being able to do further step. Then, dealing with intercultural competence, someone achieving this level is only able to discover their own cultural practices relating to target cultural content they know. Level 2 or compare and contrast, someone achieving this level is one step further than the one achieving level 1. Inside of being able to describe and identify cultural knowledge, achieving this level means that someone is also able to do such kind of comparison and contrast. In factual knowledge aspect, they are able to compare or to contrast target cultural content they know with their own perspectives. Then, dealing with intercultural competence, being in this level means that someone able to give an opinion towards target cultural practices. 
b. Level 3 or analysis, being in this level means that someone instead able to discover and identify, compare and contrast, is also able to present further analysis towards target cultural content. In term of factual knowledge, someone being here is able to analyze target cultural knowledge which differs to theirs. In term of intercultural competence, they are able to analyze and give opinions without underestimating on how cultural practices and assumptions impact individuals in the specific context.

c. Level 4 or evaluation and reflection, being here means that someone already achieves the highest level of cultural awareness. Someone achieving this level is able to evaluate and reflect any target cultural aspects they know. In term of factual knowledge, someone being here is able to connect target cultural practices or believes to the historical background or issues existing in place where the cultural contents come from. In term of intercultural competence, being here means that someone is able to give points of view dealing with target cultural content.

\section{CULTURE AND LANGUAGE LEARNING}

Language is a symbol of a culture; it can show the cultural reality around its user (Kuhi, 2013: 515). Considering this, it is no doubt that language and culture cannot be separated. Both language and culture are integrated. It is synchrony as what Lambert says in his book is that the nature of cultural knowledge is acquired through the variants level of language competence (as cited in Byram and Feng, 2004: 149).

Basically, in language learning, there are two kinds of competence in general that should be more emphasized. The first is communicative competence. It is a kind of fundamental competence that deals with the social competence, linguistic competence, and communication competence; the way in which people interact each other, transact any messages, and so on. Spietzberg states that communicative competence makes people easily address the links between communication processes and functional outcomes (Spietzberg and Cupach, 1984: 33). The second is intercultural competence. It deals with the ability of learners to be aware, understand, 
accept, appreciate, respect, value, and develop anything included in other culture (Dardoff, 2004: 43).

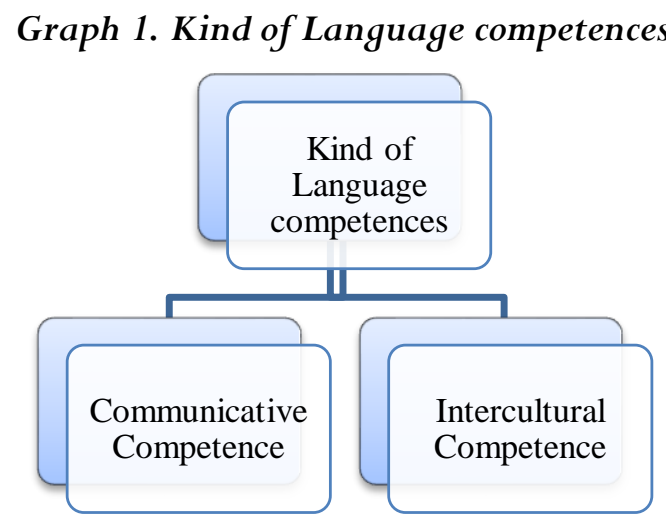

Many experts have dealt with the belief that it is imprecise and imperfect to conduct foreign language teaching without incorporating culture inside it (Genc and Bada, 2005: 73). It means that the demand for teachers to engage the target language culture in their teaching becomes something important to fulfill. If it is not, there will be such kind of disconnection in the language teaching itself. Furthermore, Genc and Bada state that the teaching-learning process inside the classroom will not be meaningful if the students have no knowledge about the people using the target language or the country where it is spoken (2005: 73). This fact stimulate a new phenomenon in which culture becomes the main additional topic engaged which is emphasized in L2 curriculum designs and textbooks.

Actually, the demand to integrate culture in language teaching is still debatable. The contrary side to this belief is represented by Sapir. Sapir, as cited by Genc and Bada, argued that 'language, race, and culture are not necessarily correlated' (2005: 74). However, believing that integrating culture in language teaching is extremely needed, for the reason that it will be difficult for the students to use the language appropriately if they have no background on how to use the language practically.

Kitao states that studying the target culture besides target language will provide students with strong willingness to learn the target culture in depth (Genc and Bada, 2005: 74). This means that 
without involving cultural aspect, the study of target language will only pass and leave no effect or trace on one's life. In analogy, it is regarded that target language and the study of linguistic items as body. In other side, the study of culture integrated will be like the soul that will give a power to the body to feel the life.

Second, the incorporation of culture in language teaching will provide knowledge to students that will help them in shaping their perspective about target language (Kitao as cited in Genc and Bada, 2005: 74). This fact will lose the distance between the foreign languages that are studied by students with the real condition where the languages are used. There are many cases in which English is learned by people in the very long time, but has no function when they are demanded to use it. The reason why it happened is just because they do not learn English through the way to use it.

Third, integrating culture in language teaching will increase students' motivation to learn the language itself (Kitao as cited in Genc and Bada, 2005: 74). Culturally based activities such as singing, dancing, role playing, and soon will attract students much better than the way how the language taught traditionally. It is already proven by the experience in teaching in which the students feel better in studying when they were provided not only by the linguistic and grammatical transfer, but also the integration of any information about culture.

Schulz maintained that actually there are three broad goals which are realistic for foreign language learners (2007: 15):

a. Students should acquire the knowledge dealing with any cultural information about the target culture

b. Students need to develop understanding; it deals with the ability of students to develop more understanding about the cultural information they get. In other words, the students are able to redefine the culture they learn through their own point of view

c. The third goal discusses merely on the way how the students develop behavior toward the target culture, moreover in broader intercultural relationship

Dealing with incorporating culture in English language teaching, Rodliyah and Muniroh summed up the theories stated by some experts about the way to incorporate culture in language 
teaching, later the following techniques will be made as a checklist used to examine whether the students of micro teaching class are able or not to engage culture in their teaching. The techniques are:

a. Providing more authentic materials involving target cultural and social elements

b. Introducing or using native idioms, proverbs, or sayings in teaching-learning process

c. Using pictures, maps, realia, posters, etc. to help students develop a mental image

d. Comparing and contrasting home and target cultures

e. Role plays, where students can learn the difference of attitudes/values of different characters associated with the culture

f. Design a project where students can have an exchange with people from different culture

Cakir (2006: 4) on his research also states some techniques that can be used to incorporate cultural competence in English language teaching, they are:

a. Providing students with culture based activities, such as singing, reading, film, simulation, and so on. It is also further asserted by Choudhory that film and so on can be one of techniques for incorporating target cultural content into ELT.

b. Providing students with any topic talking about culture whether the surface or the depth one. Liu also explored several kinds of topics that can be used to incorporate culture into ELT, such as Holidays, Christmas, Lunar New Year, and vice versa (2014: 244245).

Dai also contributes a technique that can be used by the teacher to help them incorporating culture into their teaching, that is positive classroom interaction (2011: 1034).

\section{CONCLUSIONS AND SUGGESTIONS}

The relations between students level of cultural awareness and the techniques they use for incorporating target language content into EFL teaching

However, the level of students' cultural awareness as mentioned in the previous chapter gives no impact to the techniques 
they used for incorporating target cultural content into their teaching. It was proven by the fact that the level comes with highest frequency of students using the techniques for incorporating target cultural content is level 2. Then, it was followed by level 3. While level 4 or the highest level only took the third position. And level 1 took the fourth position.

There are some suggestions coming up as the following:

a. For English Teacher Education Department, there should be the more massive effort to raise students' awareness to incorporate target cultural content into English language teaching because there are still many students do not do it in their teaching.

b. For students, although there is no impact of cultural awareness level to techniques for incorporating target cultural content into teaching, raising their cultural awareness is still quiet critical to up their proficiency of English. Having good cultural awareness however will shape people to have better view towards target language and its origin. Students also need to raise their awareness on the importance of integrating cultural content into language teaching.

c. For the next researcher, this thesis can be an initiation to do further examination on the integration of culture and language teaching. A research on teacher's belief toward the integration of culture and language in teaching or experimental study which incorporating culture becomes the object is interesting to conduct.

d. For the readers, hopefully this thesis will inform something beneficial and important to notice.

\section{REFERENCES}

Barker, C. (2008). Cultural Studies: Theory and Practice. Third ed. London: Sage.

Bianco, J. L., Liddicoat, A. J., \& Crozet, C. (1999). Striving for the Third Place: Intercultural Competence through Language Education. Melbourne: Language Australia. Retrieved from: http:/ / files.eric.ed.gov/fulltext/ED432918.pdf 
Brown, H. D. (2003). Language Assessment Principles and Classroom Practices. UK: Longman Press.

Byram, M. \& Feng, A. (2004). Culture and Language Learning; Teaching, Research and Scholarship. Language Teaching. 37(3), pp 149-168. doi:10.1017/S0261444804002289.

Cakir, I. (2006). Developing Cultural Awareness in Foreign Language Teaching. Turkey: Krikkale University

Dardoff, D. K. (2004). The Identification and Assessment of Intercultural Competence as A Student Outcome of Internalization at Institution of Higher Education in the United States. Reigh: North Carolina State University.

Genc, B. \& Bada, E. (2005) Culture in Language Learning and Teaching. The Reading Matrix, 5(1), pp. 73 - 84. Retrieved from: http://www.readingmatrix. com/articles/genc_ bada/article.pdf

Hofstede, G., (1980) Culture and Organizations. International Studies of Management \& Organization. 10(4), pp. 15 - 41. Retrieved from: http: / / www.acis.pamplin.vt.edu/faculty/ tegarden/5034/handouts/Paper/40396875.pdf

Kuhi, D. \& Mehrzad Hosseini Asl, (2013). The Relationship between Awareness Raising Activities and Students' Proficiency in Reading Comprehension of Culturally- Bound Materials. Mediteranian Journal of Social Sciences, 4(3), pp. 515 - 522. Doi:10.5901/mjss.2013.v4n3p515

Liu, Y. (2014). The Use of Target-Language Cultural Contents in EFL Teaching. International Journal of Humanities and Social Science, 4(6), pp. 243-247. Retrieved from: http://www.ijhssnet.com/journals/Vol_4_No_6_1_April_2 014/25.pdf

Menteri Pendidikan dan Kebudayaan Republik Indonesia, Kemendikbud. (2013). Peraturan Menteri Pendidikan dan Kebudayaan Republik Indonesia Nomor 70 Tahun 2013 Tentang Kerangka Dasar dan Struktur Kurikulum Sekolah Menengah Kejuruan/Madrasah Aliyah Kejuruan. Jakarta: Kemedikbud. 
Moran, P. R. (2001) Teaching culture; perspective in practices. Boston, MA: Heinle and Heinle.

Notez, C., \& Harcourt, H. M. (2013). Material and Non Material Culture. http://www.cliffsnotes.com/ sciences/sociology/ culture-and-societies/material-and-nonmaterial-culture. Accessed on 12, 23, 2013 at 13.15

Rizal Kurniansah. "Peluang dan Tantangan Pekerja Pariwisata dalam Menghadapi Era Masyarakat Ekonomi Asean (MEA) 2015” Academia.edu, (http://www.academia.edu/9069749/PELUANG_DAN_TA NTANGAN_PEKERJA_PARIWISATA_DALAM_MENGHA DAPI_ERA_MASYARAKAT_EKONOMI_ASEAN_MEA_20 15, accessed on April 24, 2015)

Rojab Siti Rodliyah R. \& Dian D. Muniroh. "The Importance of Incorporating the Target Culture in English Language Teaching” Jurusan Pendidikan Bahasa UPI, Retrieved from: http: / / file.upi.edu/Direktori/FPBS/JUR._PEND._ BAHASA_INGGRIS/197308062002122ROJAB_SITI_RODLIYAH/The_Importance_of_Incorporatin g_the_Target_Culture_in_Englis.pdf

Schulz, R. A. (2007). The Challenge of Assessing Cultural Understanding in the Context of Foreign Language Instruction. Foreign Language Annals, 40(1), pp. 9 - 26. DOI: 10.1111/j.1944-9720.2007.tb02851.x

Spietzberg \& Cupach, Interpersonal Communication Competence (London: Sage, 1984), 70-71 as cited by Darla K Deardorff in her dissertation entitled 'The Identification and Assessment of Intercultural Competence as A Student Outcome of Internalization at Institution of Higher Education in the United States 